\title{
Positive, humane and expeditious? An analysis of Ireland's implementation of its obligations in relation to family reunification under the CRC
}

\author{
CATHERINE KenNY*
}

National University of Ireland, Galway

\begin{abstract}
$\underline{\text { Abstract }}$
This paper will examine legislative and policy provisions relating to family reunification of persons granted international protection in Ireland and whether these comply with the Convention on the Rights of the Child (CRC). For the most part, the families involved can only bope to reunite in Ireland because return to the country of origin or a third country is impossible. Although the principle of family unity is generally expected in human rights instruments, the CRC is the only widely ratified international human rights instrument to include specific articles addressing the issue of family reunification, and this paper will assess compliance with those articles, and with the core principles obliging states to ensure that the views of children must be heard in all matters relating to them, and making "the best interests of the child" a primary consideration in all decisions concerning children. It will also address the issue of how Ireland's implementation of its obligations under the CRC in respect to family reunification cannot be addressed in isolation from its policies to reduce the number of asylum claims which have seen the number of applications fall in 2010 for the eighth successive year, and its failure until relatively recently to provide adequate care and support for separated children seeking asylum.
\end{abstract}

\section{Introduction}

$\mathrm{T}$ This paper will examine legislative and policy provisions relating to family reunification for persons granted international protection in Ireland and whether these comply with the CRC. For the most part, such families can only hope to reunite in Ireland because a return to the country of origin or a third country is impossible. Although the principle of family unity is generally expected in human rights instruments, the CRC is the only widely ratified international human rights instrument to include specific articles addressing the issue of family reunification.

Prolonged separation from their families can have detrimental and long-lasting effects on children, in particular unaccompanied and separated children, and this was recognised by the drafters of the CRC. The only article directly addressing the issue of family reunification - Article 10.1 - requires states to ensure that applications for family reunification involving children are dealt with in a "positive, humane and expeditious way". The Convention also obliges states to ensure that children will not be separated from their parents without their consent except in very limited circumstances and only in the best

* PhD candidate, Irish Centre for Human Rights, National University of Ireland, Galway. 
interests of the child. The rights of refugee children are addressed in Article 22. It sets out, inter alia, the obligation on states to cooperate in tracing family members of refugee children for the purposes of reunification. In addition, a number of key principles, including that obliging states to ensure that the views of children must be heard in all matters relating to them, and to make "the best interests of the child" a primary consideration in all decisions concerning children, are also relevant.

Many EU states including Ireland have sought to reduce the numbers of applications for asylum and other forms of international protection in recent years. In addition, many states have sought to place barriers in the way of migrants, including those granted international protection, seeking to reunite with family members.

Alice Edwards has pointed out that host states increasingly adopt restrictive measures in relation to refugees:

either through narrow definitions of who constitute a family, the imposition of immigration type criteria on reunification applications ... or even bars to family reunifications until after a specified period of time has elapsed. ${ }^{1}$ Furthermore, the United Nations High Commission for Refugees (UNHCR) has noted that some states prohibit separated refugee children from applying for family reunification and still others put in place restrictive conditions making reunification difficult or even impossible to achieve for many refugee children. ${ }^{2}$

Ireland's implementation of its obligations under the CRC in respect of family reunification cannot be addressed in isolation from these international developments and from its own policies to reduce the number of asylum claims, which have seen the number of applications fall in 2010 for the eighth successive year, ${ }^{3}$ and its failure until relatively recently to provide adequate care and support for separated children seeking asylum.

This article commences by examining family separation in the international protection context and its impact on children. It goes on to briefly consider the principle of family unity and whether the protection afforded to the family unit in international law implies a right to family reunification. The right to family reunification for refugees and other beneficiaries of international protection is considered. While it is recognised that most Western states permit refugees and in certain circumstances other beneficiaries of international protection to be joined by family members, such family reunification provisions are often restrictive and dependent on government policy. The provisions of the CRC will then be considered and the "expansive" views of the Committee on the Rights of the Child expounded in its general comments and concluding observations on states' periodic reports will also be examined. Finally, Ireland's legislation and policy in relation to family reunification and whether it complies with the states' obligations under the CRC will be analysed.

\section{Family separation and its impact on the child}

\section{FAMILY SEPARATION}

War, conflict and human-rights abuses result in family separation with almost 220,000 separated children registered by the International Committee of the Red Cross in Rwanda

1 A Edwards, "Human rights, refugees and the rights 'to enjoy' asylum" (2005) 17(2) International Journal of Refugee Law 293-330, p. 308.

2 UN High Commissioner for Refugees, Global Consultations on International Protection/Third Track: Refugee Children, 25 April 2002, EC/GC/02/9, available at www.unhcr.org/refworld/docid/ 3d6268f64.html.

3 “Asylum claims fell by 28\% last year", Irish Times, 7 January 2011. 
alone. ${ }^{4}$ The Inter-Agency Guiding Principles on Unaccompanied and Separated Children enumerate factors leading to separation of children from their families:

Separation occurs either accidentally - when fleeing from danger or during evacuation - or deliberately when children are abandoned or given over to the care of another individual or a residential centre, perhaps in the belief that they will have a better chance of survival or access to services. ${ }^{5}$

Staver identifies three ways in which families can be separated. First, accidental separation, where, for example, family members follow different routes of escape from conflict. The second way may arise because of a temporary strategy, whereby a member of the family at particular risk, for example, a girl child at risk of female genital mutilation, may be sent to safety. Thirdly, separation may occur when members of the family are imprisoned or abducted. ${ }^{6}$ Hathaway has noted that in extreme circumstances some parents may be "compelled" to take the difficult step of separating from their children to enable the children "to take advantage of superior opportunities often available to unaccompanied minors". 7

Flight from the country of origin with all its attendant dangers can lead to further division among families, with some members reaching safety and others remaining in the conflict zone, their hope of resuming family life dependent on the family reunification policies of the country of refuge.

\section{THE IMPACT OF SEPARATION ON THE CHILD}

Even where states ensure family reunification takes place in an expeditious manner, many refugee families are separated for considerable periods due to the lengthy processing times for applications for refugee status or other forms of international protection. In some countries, this process can take several years. This has negative implications not just for the families themselves but also for the host state. The integration of refugees in the host community which is beneficial to both refugees and the host state is facilitated by family reunification. 8 The lengthy processing time may cause irreparable damage to family relationships. As Jastram and Newland have noted:

the passage of time alone is damaging to the family, and costly to States, since the likelihood of social problems and even family breakdown is higher with longer periods of separation and this may result in increased costs for States in welfare and other support services. ${ }^{?}$

Lengthy separation from parents and other family members can often have a profound effect on children and they can experience difficulties in establishing family relationships with their parents and other family members when reunification is finally granted. However, studies have shown that "children can cope with horrible experiences and high levels of

4 A Staver, Family Reunification: A right for forced migrants?, Working Paper No. 51 (Oxford: Refugee Studies Centre 2008), p. 5.

5 International Committee of the Red Cross, Inter-Agency Guiding Principles on Unaccompanied and Separated Children (Geneva: ICRC 2004), p. 22.

6 Staver, Family Reunification, n. 4 above, p. 5.

7 J C Hathaway, The Rights of Refugees under International Law (Cambridge: CUP 2005), p. 534.

8 UNHCR, Note on Family Protection Issues, EC/49/SC/CRP, 14 June 1999, para. 16. See also, UNHCR, Targeted or Mainstream Support to Refugee Integration? Legislation, policy and support in Ireland and selected European countries (Dublin: UNHCR April 2009), p. 45.

9 K Jastram and K Newland, "Family unity and refugee protection", in E Feller, V Türk, and F Nicholson (eds), Refugee Protection in International Law: UNHCR's global consultations on international protection (Cambridge: CUP 2003), pp. 555-603, p. 559. 
stress if they have a secure relationship with parents or effective adult substitutes". ${ }^{10}$ Separation from family members, in particular parents, lessens the ability to cope with difficult situations and may lead to long-term problems for the child.

A recent study on the experiences of Somali refugees in Ireland has found that: "The obstacles young and adult refugees encounter in matters related to family reunification have fundamental repercussions on their economic and psychological well-being." It noted that research participants felt "powerless and overwhelmed" by their responsibilities to family members in the country of origin. ${ }^{11}$ There is no reason to believe that the experiences of Somali refugees in relation to family reunification are atypical.

\section{The principle of family unity}

The family is universally recognised as "the fundamental group unit of society". International and regional human rights instruments also recognise people have a right to enjoy their privacy and family life without unlawful or arbitrary interference. Article 17, para. 1 of the 1966 International Covenant on Civil and Political Rights (ICCPR) reiterates a similar provision in the Universal Declaration of Human Rights and prescribes that "no one shall be subjected to arbitrary or unlawful interference with his . . . family", while Article 23.1 of the ICCPR, adds that "the family is the natural and fundamental group unit of society and is entitled to protection by society and the State". ${ }^{12}$

States parties are obliged to ensure that the above rights are to be enjoyed by all individuals "without distinction of any kind". ${ }^{3}$ The UN Human Rights Committee recognises that the right to form a family and family life implies reunification in the case of migrants who have been separated. ${ }^{14}$ Under Article 10 of the International Covenant on Economic, Social and Cultural Rights, states have undertaken to provide "the widest possible protection and assistance" to the family. ${ }^{15}$ In its General Comment No. 19 on Protection of the Family, the Right to Marriage and Equality of the Spouses, the Committee states that:

the right to found a family implies, in principle, the possibility to live together ... the possibility to live together implies the adoption of appropriate measures, both at the internal level and as the case may be in cooperation with other States to ensure the unity or reunification of families, particularly when members are separated for political, economic or similar reasons. ${ }^{16}$

10 C L Barwick, B Morton and G Edwards, "Refugee children and their families: exploring mental health risks and protective factors", in F J C Azima and N Grizenko (eds), Immigrant and Refugee Children and their Families: Clinical, research and training issues (Madison CT: International UP 2002), p. 49, cited in Staver, Family Reunification, n. 4 above, p. 6.

11 E Moreo and R Lentin, From Catastrophe to Marginalisation: The experiences of Somali refugees in Ireland, Migrant Networks Project, Trinity Immigration Initiative (Dublin: Trinity College Dublin in Association with HAPA (Horn of Africa People's Aid) 2010), p. 48.

12 International Covenant on Civil and Political Rights 1966 (ICCPR), 999 UNTS 171.

13 Article 2(1) ICCPR.

14 The Human Rights Committee is the body of international experts tasked with monitoring the implementation of the ICCPR.

15 UN General Assembly, International Covenant on Economic, Social and Cultural Rights, 16 December 1966, UN Treaty Series, vol. 993, p. 3, Article 10(1).

16 Committee on the Rights of the Child, General Comment No. 19, Article 23 (39th session, 1990), Compilation of General Comments and General Recommendations adopted by Human Rights Treaty Bodies, UN Doc. HRI/GEN/1/Rev. 6 at 149 (2003), para. 5. 
Regional instruments including the European Convention on Human Rights also guarantee respect for family life and require states not to interfere with that right in an arbitrary or unlawful manner. ${ }^{17}$ Under the European Social Charter, states, recognising the position of the family as the fundamental group unit, undertake to promote the economic, legal and social protection of family life. ${ }^{18}$

While the principle of family unity and the right to family life free from arbitrary interference are well-established principles in international human rights law, the question is whether a right to family reunification can be inferred, even in cases where family unity cannot be enjoyed elsewhere. The UNHCR has argued that, especially where a family has no realistic hope of reunification elsewhere, refusal of family reunification could be seen as an interference with family life or family unity. ${ }^{19}$ As Cholewinski has noted:

To move from the protection of the family unit provided by international human rights law to the recognition of the right to family reunification in the immigration field is not such a significant step to take. ${ }^{20}$

Nevertheless, as he points out, this step has not been taken in an unequivocal manner in any human rights treaties. ${ }^{21}$ While human rights law does not specifically recognise the right to family reunification, it is accepted that the right to form a family implies the right of that family to live together and that this may necessitate action by states to ensure the unity of families when "members are separated for political, economic or similar reasons". 22

\section{The right to family reunification for refugees and other beneficiaries of international protection 23}

For the purpose of this article, family reunification can be described as the social and legal process of reunion of a principal protection status holder with his or her family members in the host state. Family reunification entails bringing separated family members across international borders which, as a number of commentators have recognised, is "a politically sensitive activity". 24 In the case of refugees or other beneficiaries of international protection, reunification means uniting separated family members with the status holder in the country of asylum. ${ }^{25}$ According to the Committee on the Rights of the Child, "the granting of refugee status constitutes a legally binding obstacle to the country of origin and

17 European Convention for the Protection of Fundamental Freedoms 1950 (ECHR), ETS No. 5, Article 8.

18 Council of Europe, European Social Charter, ETS No. 163, Article 16.

19 UNHCR, Summary Conclusions on Family Unity (Cambridge: CUP June 2003), available at www.unhcr.org/ refworld/docid/470a33bed.html.

20 R Cholewinski, "Family reunification and conditions placed on family members: dismantling a fundamental human right" (2002) 4 European Journal of Migration and Law 271-90, p. 275.

21 Ibid. p. 275

22 Committee on the Rights of the Child, General Comment No. 19: Protection of the Family, the Right to Marriage and Equality of the Spouses (Article 23), 27 July 1990, para. 5.

23 Family reunification for the purposes of this article refers only to the reunification of family members with refugees and other beneficiaries of international protection in the host state.

24 B McDonald-Wilmsen and S M Gifford, Refugee Resettlement, Family Separation and Australia's Humanitarian Programme, New Issues in Refugee Research: Research Paper No. 178 (Geneva: UNHCR November 2009).

25 The 1951 Refugee Convention relative to the status of refugees defines a refugee as a person who "owing to a well-founded fear of being persecuted for reasons of race, religion, nationality, membership of a particular social group or political opinion is outside the country of his nationality and who is unable or, owing to such fear, is unwilling to avail himself of the protection of that country". Other beneficiaries of international protection include people who do not meet the criteria for refugee status and are granted a lesser form of protection sometimes referred to as complementary or subsidiary protection. 
consequently to family reunification therein". ${ }^{26}$ Despite the lack of alternatives open to these families, some host states restrict family reunification rights for refugees and other beneficiaries of protection.

The 1951 Refugee Convention, which is not strictly a human rights instrument, is silent regarding family reunification for refugees. However, this does not mean that the drafters failed to recognise the importance of family life to refugees. They recommended in relation to family unity that:

[states] take the necessary measures for the protection of the refugee's family especially with the view to ... ensuring that the unity of the refugee's family is maintained particularly in cases where the head of the family has fulfilled the necessary conditions for admission to a particular country 27

The office of the UNHCR which is responsible for monitoring and providing guidance to states on the implementation of the Refugee Convention has advanced family reunification rights for refugees in the Handbook on Procedures and Criteria for Determining Refugee Status, which emphasises the importance of the right to family unity for refugees and the recommendations of the Convention drafters. ${ }^{28}$ In addition, UNHCR's Executive Committee (EXCOM) has also issued a number of conclusions in relation to family unity and family reunification. In Conclusion 24, EXCOM urges states to ensure that reunification takes place with "the least possible delay" and to apply "liberal criteria" when considering which family members to admit for the purposes of reunification. Furthermore, in recognition of the difficulties refugees have in accessing documentation, it advises states not to refuse applications for family reunification solely on the basis of a lack of documentary evidence of marriage or parentage of children. ${ }^{29}$ EXCOM also recommends that family reunification should be guaranteed at least to "the spouse and minor dependent children of any person to whom temporary refugee or durable asylum has been granted". 30

At EU level, two key directives deal with family reunification for refugees while the Council Regulation (EC) No. 343/2003 (hereinafter the Dublin II Regulation) provides for limited family unity rights for people seeking asylum. The Directive on Family Reunification sets out the conditions under which third-country nationals residing lawfully on the territory of the member states may exercise the right to family reunification. ${ }^{31}$ The directive narrowly defines the family unit, restricting it to parents and siblings. ${ }^{32}$ It also allows member states to restrict the provisions of the directive to situations where the family was formed before

26 Committee on the Rights of the Child, General Comment No. 6: Treatment of Unaccompanied and Separated Children outside their Country of Origin (hereinafter General Comment No. 6) CRC/GC/2005/6, 1 September 2005, para. 82.

27 Final Act of the United Nations Conference of Plenipotentiaries on the Status of Refugees and Stateless Persons, 1951 UN Doc. A/CONF.2/108/Rev.1, 26 November 1952, Recommendation B.

28 UNHCR, Handbook on Procedures and Criteria for Determining Refugee Status under the 1951 Convention and the 1967 Protocol relating to the Status of Refugees, HCR/IP/4/Eng/Rev. 1 (Geneva: UNHCR 1979, re-edited January 1992), paras 181-8.

29 UNHCR, Executive Committee (EXCOM) Conclusions, Family Reunification (No. 24 (XXXII) 1981). EXCOM conclusions are not legally binding but are reflective of the views of EXCOM member states (currently comprising 79 states) and are therefore influential.

30 UNHCR, EXCOM Conclusions, Refugees Without an Asylum Country (No. 15 (XXX) 1979).

31 Council Directive 2003/86/EC of 22 September 2003 on the right to family reunification (hereinafter the Family Reunification Directive). While the directive applies to migrants generally, it contains a specification relating to refugees: ch. V "Family reunification of refugees".

32 Family Reunification Directive, Article 10(1). 
the arrival of the refugee in the particular member state. ${ }^{33}$ Where the refugee is a child, family reunification provisions are limited to the parents and where they are deceased or cannot be traced, the child's guardian or other family members may be allowed to join him or her. ${ }^{34}$ Ireland has exercised its right to opt out of this directive.

Council Directive 2004/83/EC of 29 April 2004 (hereinafter the Qualification Directive), in addition to laying down minimum standards for granting international protection, also provides for the rights that will accrue to individuals granted protection. ${ }^{35}$ Member states have undertaken that the best interests of the child shall be a primary consideration when implementing provisions relating to the content of protection including family reunification. ${ }^{36}$ However, the definition of family in the directive is narrow and only family relationships existing in the country of origin will be recognised for the purposes of family reunification; the directive does not consider family relationships formed during flight or in the country of asylum. ${ }^{37}$

In most states, people seeking a declaration of their status as a refugee have few rights, including the right to family unity. ${ }^{38}$ Asylum seekers are, as Bhabha noted, "a temporary and increasingly disenfranchised category of non-citizens" with very few rights in many countries of refuge. ${ }^{39}$ However, EU law recognises limited rights to family unity for asylum seekers. In February 2003, the Council of the European Union adopted the Dublin II Regulation establishing the criteria and mechanisms for determining the member state responsible for examining an asylum application lodged in one of the member states by a third-country national. The Dublin II Regulation sets out a system for determining responsibility among EU states for examining asylum claims.

Article 6 of the regulation provides that, if an unaccompanied minor makes an application for a declaration as a refugee, responsibility for determining the claim rests with the member state where a member of his or her family is legally present if that is in the best interests of the child. If there are, however, no members of the minor's family legally present, the country where the minor makes the application is responsible for the claim. Research carried out by the UNHCR has revealed that, despite states' obligations under Article 6, in some cases the article is applied incorrectly and unaccompanied minors remain separated. ${ }^{40}$

Article 7 provides for reunification of an asylum seeker with family members who are recognised as refugees in another member state irrespective of whether the family was formed in the country of origin. If the asylum seeker has a family member in a member state whose application has not yet been the subject of a first decision regarding the substance, that member state shall be responsible for examining the application for asylum. In both circumstances, reunification will only be possible if both parties agree. The UNHCR study again found inconsistencies in the practice of states in relation to these articles. ${ }^{41}$

33 Family Reunification Directive, Article 9(2).

34 Ibid. Article 10(3).

35 Council Directive 2004/83/EC of 29 April 2004 on minimum standards for the qualification and status of third-country nationals or stateless persons as refugees or as persons who otherwise need international protection and the content of the protection granted (hereinafter, the Qualification Directive).

36 Qualification Directive, Article 20(5).

37 Ibid. Articles 4(1) and 23(5).

38 Hathaway, The Rights of Refugees, n. 7 above, p. 535.

39 J Bhabha, "International gatekeepers? The tension between asylum advocacy and human rights" (2002) 15 Harvard Human Rights Journal 155-82, p. 155.

40 UNHCR, The Dublin II Regulation: A UNHCR discussion paper (Geneva: UNHCR 2006), pp. 21-2.

41 Ibid, p. 26. 
It is widely acknowledged that the notion of "family" varies throughout the world from the narrow, nuclear family in many Western states to the more inclusive extended family common in many African and Asian states. Therefore, "from a cross cultural perspective, the meaning of family - who is in the family and who is not - is not fixed and the configuration of family is made even more complicated". ${ }^{42}$ The UNHCR endeavours to respect the "culturally diverse interpretation of family" if it respects human rights standards. UNHCR's definition of family also includes "persons who may be dependent on the family unit, particularly economically but also socially or emotionally dependent". ${ }^{43}$ The notion of "family" is not a static concept, however, and family forms are changing both in countries of origin (for example, as they become urbanised) and in traditional countries of asylum where the family based on marriage is often no longer the predominant family type.

\section{The CRC and family reunification}

This section examines what are the key obligations imposed on states under the CRC in relation to family reunification and whether these add to the rights already set down in international law. The Preamble to the Convention recognises the family as "the natural environment for the growth and well-being of all its members and particularly children" and goes on to state that in order for the "full and harmonious development" of a child's personality, he or she should grow up in a happy and caring family environment.

The CRC defines a "child" as being a person under the age of $18 .{ }^{44}$ However, some states only consider applications for family reunification for children under the age of 15.45 In addition, the Convention does not define family, merely laying down obligations where children are separated across international borders from "their parents". 46 Similarly, the Committee on the Rights of the Child clarifies states' obligations in relation to reunification of children with their parents in its General Comment on the Treatment of Unaccompanied and Separated Children outside their Country of Origin. ${ }^{47}$

Article 9 obliges states to ensure that children will not be separated from their parents without their consent. Article 9.1 states:

States Parties shall ensure that a child shall not be separated from his or her parents against their will, except when competent authorities subject to judicial review determine, in accordance with applicable law and procedures, that such separation is necessary for the best interests of the child. ${ }^{48}$

This is the only exception permitted under the Convention and is not subject to considerations of public order, public safety, national security or other such concerns which limit the enjoyment of family life under other human rights treaties. The phrase "applicable law and procedures" is not defined in the Convention and it has not been elaborated by the

42 McDonald-Wilmsen and Gifford, Refugee Settlement, n. 24 above.

43 UNHCR, Challenges and Opportunities in Family Reunification: Annual tripartite consultations on resettlement (Geneva: UNHCR 2008), cited in McDonald-Wilmsen and Gifford, Refugee Settlement, n. 24 above.

44 Article 1 states: "For the purposes of the present Convention a child means every human being below the age of 18 years unless under the law applicable to the child, majority is attained earlier."

45 The Family Reunification Directive permitted states to introduce restrictions on family reunification for children over 15. See K Groenendijk, R Fernhout, D van Dam, R Van Oers and T Strik, The Family Reunification Directive in EU Member States: The first year of implementation (Nijmegen: Centre for Migration Law 2007), p. 17, available at http://cmr.jur.ru.nl/cmr/docs/family.rd.eu.pdf.

46 CRC, UN GA Res., 20 November 1989, Article 10.1.

47 Committee on the Rights of the Child, General Comment No. 6, paras 81-3.

48 This article does not specifically refer to separation in the migration context, however, it can be read as including circumstances where refugee or other migrant children are separated from their families. 
Committee on the Rights of the Child. It could be argued that it may cover, inter alia, law and procedure in relation to immigration. In most states the right to family unity for migrants is not absolute and in the case of beneficiaries of international protection, while generally permitted, is subject to restrictions. However, the strongly worded article, according to one commentator, requires states to "take all positive measures necessary to assure the realization of [the right to be with both one's parents]". 49

Article 10.1 obliges states to ensure that applications for family reunification involving children are dealt with in a "positive, humane and expeditious way". The Convention does not provide any further guidance in relation to the processing time. However, UNHCR states that reunification should take place without "unreasonable delay". It also recommends that expedited procedures should be put in place in cases involving separated or unaccompanied children. ${ }^{50}$ This article applies whether or not the child is the applicant for family reunification, for example, a separated child refugee applying to be joined by his or her family or an adult refugee, seeking to be joined by his or her children. Article 10 does not, however, guarantee a "right" to family reunification where children are involved and its "careful wording reflects immigration control concerns raised by some countries during the negotiation process of the Convention". 51

However, it has been argued that both provisions taken together go beyond a simple requirement on states "to efficiently process an application for family reunification" as "failing to grant family reunification rights may bring a State Party into breach of the earlier provisions not to forcibly separate children from their parents". ${ }^{2}$ Article 22 requires states to protect and assist refugee children and to trace the parents or other members of the family of any refugee child in order to obtain information necessary for reunification with his or her family. Family tracing is of particular importance to refugee children separated from their parents or customary care-giver. Many states entrust family tracing to organisations such as the Red Cross. Article 22.2 stipulates that states shall provide:

co-operation in any efforts by the United Nations and other competent intergovernmental organizations or non-governmental organizations cooperating with the United Nations to protect and assist such a child and to trace the parents or other members of the family of any refugee child in order to obtain information necessary for reunification with his or her family.

The Convention is premised on four principles, three of which have particular relevance to the issue of family reunification:

- all children should be entitled to basic rights without discrimination (Article 2);

- the best interests of the child should be a primary consideration in decisionmaking affecting children (Article 3.1);

- the views of children must be taken into account in matters affecting them (Article 12).

Article 2(1) proscribes discrimination in relation to the rights laid down in the Convention between different groups of children but also between children and adults. Bhabha pointed to one area where discrimination takes place between adults and children

49 E F Abram, "The child's right to family unity in international immigration law" (1995) 17(4) Law and Policy 397-439, p. 418, cited in Staver, Family Reunification, n. 4 above, p. 15.

50 UNHCR, Summary Conclusions on Family Unity (Cambridge: CUP June 2003), available at: www.unhcr.org/refworld/docid/470a33bed.html.

51 Office of the High Commissioner for Human Rights (OHCHR), Family Reunification, Migration Discussion Papers, available at www2.ohchr.org/english/issues/migration/taskforce/docs/familyreunification.pdf.

52 Edwards, "Human rights", n. 1 above, p. 315. 
which has a knock-on effect on family reunification, namely the reduced likelihood of children being declared refugees following an application for asylum. While, as she points out, children are not discriminated against in relation to access to the asylum process, a "considerably lower proportion" of child applicants are recognised as refugees. ${ }^{53}$ As a result, they are ineligible for the domestic family reunification procedures pertaining to refugees in the host state.

The best interests of the child standard has been included in a number of international instruments concluded since the adoption of the CRC. ${ }^{54}$ Moreover, it is adopted as policy by a wide range of bodies working with children. While this widespread acceptance of the best interests of the child principle is welcome, it remains the position that many states fall short of their obligations, in particular regarding family reunification where children are concerned. The UNHCR has noted that family reunification wherever possible should be regarded as in the best interests of the child. ${ }^{55}$ It could be argued that it is in the best interests of children separated from their parents and other close family members by migration to be reunited with them.

At EU level, immigration control often takes precedence over the best interests of the child. ${ }^{56}$ A recent report on the implementation of the EU Family Reunification Directive found that states often do not take into account in a satisfactory manner the best interests of the child, nor do they adequately apply the more favourable provisions for the family reunification of refugees. ${ }^{57}$ According to Sandy Ruxton, there is evidence to suggest that:

[children's interests are not always a] "primary consideration", when drawing up legislation and policy ... and although the "best interests" principle is positively included in recent asylum and migration instruments, it is sometimes undermined by other specific provisions or inconsistently applied in practice. ${ }^{58}$

Moreover the Committee on the Rights of the Child has also adopted a General Comment No. 6 on the treatment of unaccompanied and separated children outside their country of origin. ${ }^{59}$ In relation to family reunification, it states that, if it is not possible for the child to be united with his or her parents in the country of origin, irrespective of whether this is due to legal obstacles to return or whether the best-interests-based balancing test has decided against return, obligations under Articles 9 and 10 of the Convention are engaged, and the Committee reminds states of their obligations, in particular to deal with applications for family reunification in a positive, humane and expeditious way.

The third principle that impacts on family reunification rights, is that the views of children must be taken into account in all matters affecting them. ${ }^{60}$ This recognises the fact that although children "lack the full autonomy of adults" they are nevertheless "holders of

53 J Bhabha, "More than their share of sorrows: international migration law and the rights of children" (2003) 22(2) Saint Louis University Public Law Review 253-74, p. 259.

54 See above, the EU Qualifications and Family Reunification Directives. The best interests of the child is also reflected in human rights instruments including the ECHR, Article 24.1 and the Convention on the Rights of Persons with Disabilities, Article 7.2.

55 UNHCR, Guidelines on Determining the Best Interests of the Child (Geneva: UNHCR May 2008), para. 1.3.

56 D Sutton and T Smith, "Is Europe failing separated children" (2005) 23 Forced Migration Review 29-30, available at www.fmreview.org/FMRpdfs/FMR23/FMR2311.pdf.

57 Report from the Commission to the European Parliament and the European Council on the application of Directive 2003/86 on family reunification of third-country nationals, COM/2008/0610final.

58 S Ruxton, What about us? Children's rights in the European Union (Brussels: European Children's Network 2005), p. 13.

59 Committee on the Rights of the Child, General Comment No. 6 (2005).

60 CRC, Article 12. 
rights". The importance given to these views will be determined by the child's age and level of maturity. The Committee on the Rights of the Child notes that the right of the child to be heard places a clear obligation on states to recognise this right and to ensure its implementation by seeking the views of children and according due weight to these views. ${ }^{61}$ It goes on to state that in order to meet their obligations states are required to review or amend legislation in order to ensure that mechanisms are introduced to ensure that children receive appropriate information and adequate support in addition to feedback on the weight given to their views if necessary. ${ }^{62}$ Despite their obligations under Article 12 of the CRC, states often do not put in place measures to solicit the views of children, in particular child applicants, during the family reunification process, and in some cases states have not informed children or their guardians in the country of asylum of their family reunification rights and the procedure involved. ${ }^{63}$

An examination of the concluding reports of the Committee on the Rights of the Child reveals that many states fail to implement the CRC in an equitable manner. While the CRC does not confer an absolute right to family reunification, the Committee would appear in recent years to have adopted "an extensive interpretation" of the provisions relating to family reunification. ${ }^{64}$ This is evident from an examination of its concluding observations on states parties' periodic reports. While, on the one hand, many of the comments and recommendations seek to ensure that states parties comply with the provisions of the Convention, for example, comments in relation to the length of the procedure, others go further in dealing with the rights to family reunification where children or family members are holders of temporary protection or humanitarian visas and in requesting states to review their definition of the family for the purposes of family reunification.

The Committee urged Australia to introduce legislation and procedures "to guarantee that children of asylum seekers and refugees are reunited with their parents in a speedy manner". ${ }^{65}$ It drew the attention of a number of states to lengthy family reunification processing times. In its concluding observations on Finland's second periodic report, the Committee expressed its concern over the length of the family reunification process and the negative impact this may have on children. ${ }^{66}$ States have also been reminded of their duties to inform children of the right to make an application for family reunification and the procedure involved. The Committee urged Norway

to establish a standard procedure through which children and other concerned persons ... a are informed of the possibilities and procedures for family reunification and for these procedures to be implemented systematically in accordance with set guidelines. ${ }^{67}$

The Committee expressed its concern over legislative changes in Denmark to reduce the age limit of a child eligible for family reunification from 18 to 15 years old and

61 Committee on the Rights of the Child, General Comment No. 12: The Right of the Child to be Heard, CRC/C/GC/12, 20 July 2009 (hereinafter General Comment No. 12), para. 15.

62 Ibid. para. 48.

63 The Committee on the Rights of the Child has admonished several states parties for failing to provide information to children on their right to family reunification. See below, text relating to nn. 65-74.

64 OHCHR, Migration Discussion Paper (Geneva: OHCHR November 2005), p. 4, available at www2.ohchr.org/ english/issues/migration/taskforce/docs/familyreunification.pdf.

65 Committee on the Rights of the Child, 16th Session, Concluding Observations of the Committee on the Rights of the Child, Australia, CRC/C/15/Add. 79, 10 October 1997, para. 30.

66 Committee on the Rights of the Child, 25th Session, Concluding Observations on Finland, CRC/C/15/Add. 132, 15 October 2000, paras 37 and 38.

67 Committee on the Rights of the Child, 24th Session, Concluding Observations on Norway, CRC/C/15/Add. 126, 28 June 2000, paras 32-3. 
recommended that Denmark ensure that it complies with Article 1 of the Convention which defines a child as under the age of 18.68 The Committee also expressed its concern regarding the German requirements and procedures for family reunification for those declared a refugee under the 1951 Refugee Convention, which the Committee considered were too complex and too long. It recommended that Germany take measures to ease these procedures. ${ }^{69}$ The Committee similarly advised Canada to deal with applications for family reunification in an expeditious manner. ${ }^{70}$

In its concluding comments on France's 2009 report, it noted the lack of comprehensive information on family reunification procedures, their length and the limited possibilities for children to assert their right to family reunification when they arrive in France. It also expressed its concern "over reports on family separation due to deportation of parents due to a law which imposes on recognised refugees more restrictive criteria for family reunification including DNA testing and language proficiency". ${ }^{71}$

At the same session, the Committee urged Sweden to continue to take measures to ensure that the family reunification procedures for refugees are dealt with in accordance with Sweden's obligations under Article 10.1 in order that they do not entail infringing the rights of children under the Convention. ${ }^{72}$ In June 2010, the Committee issued a similar recommendation to Belgium, urging it also to ensure family reunification procedures were in the best interests of the child..$^{73}$ The Committee recommended that Australia should consider permitting family reunification in cases where children or their family members are holders of temporary protection or temporary humanitarian visas. ${ }^{74}$

\section{Legislation and policy on family reunification in Ireland}

Only persons recognised as refugees in Ireland and beneficiaries of subsidiary protection have a statutory right to family reunification. However, while the Refugee Act 1996 (as amended) provides for the resettlement of refugees, referred to as "programme refugees", 75 there is no provision for family reunification for such refugees, primarily as many of them, but not all, arrive as part of a family group. In addition, Irish citizens have no statutory rights to family reunification with non-European Economic Area family members. Individuals who naturalise as Irish citizens do not gain any additional rights to

68 Committee on the Rights of the Child, 40th Session, Concluding Observations on Denmark, CRC/C/DNK/CO/3, 23 November 2003, para. 32.

69 Committee on the Rights of the Child, 51st Session, Concluding Observations on Germany, CRC/C/15/Add. 226, 26 February 2004. This periodic review took place prior to the implementation of the Qualification Directive.

70 Committee on the Rights of the Child, 51st Session, Concluding Observations on Canada, CRC/C/15/Add. 215, 27 October 2003, para. 47(f).

71 Committee on the Rights of the Child, 51st Session, Concluding Observations on France, CRC/C/FRA/CO/4, 11 June 2009, para. 10.

72 Committee on the Rights of the Child, 51st Session, Concluding Observations on Sweden, CRC/C/SWE/CO/4, 12 June 2009, para. 65.

73 Committee on the Rights of the Child, 54th Session, Concluding Observations on Belgium, CRC/C/BEL/CO/3-4, 18 June 2010, paras 74(d) and 75(c).

74 Committee on the Rights of the Child, 40th Session, Concluding Observations on Australia, CRC/C/15/Add. 268, 20 October 2004, para. 65(e)

75 Article 24 of the Refugee Act 1996 (as amended) defines "a programme refugee" as "a person to whom leave to enter and remain in the state for temporary protection or resettlement as part of a group of persons has been given by the Government and whose name is entered in a register established and maintained by the Minister for Foreign Affairs, whether or not such person is a refugee within the meaning of the definition of 'refugee' in section 2'. 
family reunification and refugees and beneficiaries of subsidiary protection lose their statutory right to be joined by their families.

While family reunification rights for those granted international protection are provided for in legislation, the procedure is often lengthy and bureaucratic. In addition, individuals who are granted leave to remain subsequent to a negative asylum determination do not have a right to family reunification irrespective of the ground(s) on which leave to remain was granted.

Section 18 of the Refugee Act 1996 (as amended) governs the right to family reunification for recognised refugees in Ireland. ${ }^{76}$ Two categories of family reunification are provided for. A refugee is entitled to be reunited with his or her immediate family members (subject only to national security concerns and public policy), defined narrowly as the spouse and unmarried child of an adult refugee and in the case of refugee children, the parents of the refugee. A discretionary system by which the minister may also grant permission to reside in the state to a dependent member of the refugee's family is also provided for under this section. Article 18(4)(b) of the Refugee Act 1996 defines "dependent member of the family", in relation to a refugee, as:

any grandparent, parent, brother, sister, child, grandchild, ward or guardian of the refugee who is dependent on the refugee or is suffering from a mental or physical disability to such extent that it is not reasonable for him or her to maintain himself or herself fully.

Section 18 also sets out the procedure for applications for family reunification. A refugee in respect of whom a declaration is in force may apply to the Minister for Justice for permission to be granted to his or her family to enter and reside in the state. The application is subsequently referred to the Refugee Applications Commissioner who is required to investigate the application and submit a report in writing to the minister, setting out "the relationship between the refugee concerned and the person the subject of the application and the domestic circumstances of the person". If the minister is satisfied that the person is a member of the family of the refugee, he or she will grant permission to the person to enter and reside in the state. This applies both to immediate and dependent family members. The legislation fails to provide for an independent appeals process in cases where permission for reunification has been refused. It is open to refugees and beneficiaries of subsidiary protection whose applications have been unsuccessful to make a new application, further prolonging the separation from family members.

Child applicants for family reunification in Ireland must go through the same application process as adults. Such procedures fail to take account of the particular needs of children and their levels of understanding. It may be argued that children in the family reunification process, in particular child applicants, are considerably disadvantaged by legislation and procedure which fails to fully comply with Ireland's obligations under the CRC. This can been seen most clearly in relation to a number of issues including the discriminatory nature of dependency requirements, the lengthy procedural delays and the failure to take into consideration the views of the child regarding family reunification - a matter that is clearly central to their lives.

76 Identical provisions also apply to beneficiaries of subsidiary protection under s. 16 of the European Communities (Eligibility for Protection) Regulations 2006 (SI 518/2006). 


\section{DEPENDENCY AND CHILD APPLICANTS}

A separated child, declared a refugee in Ireland, is automatically entitled to apply for reunification with his or her parents, but the refugee child must demonstrate that any siblings are dependent on him or her, an onerous task, particularly as most separated children are in full-time education. This is surely not in keeping with the spirit of the CRC. According to the Irish Refugee Council:

The definition of dependent family members in Irish legislation works in favour of adults and discriminates against children who self-evidently will not be able to prove that others depend on them financially. ${ }^{77}$

Moreover, a successful application may result in parents facing a choice of whether to join their child in Ireland, leaving their remaining children alone in the country of origin, or to remain in the country of origin with their other children. ${ }^{78}$ Such a narrow definition of the refugee child's family is hardly in keeping with a positive and humane approach to applications for family reunification stipulated in the CRC. There is no provision for a refugee or beneficiary of subsidiary protection to be joined by a family member other than a parent on whom he or she is dependent, again putting child refugees or beneficiaries of subsidiary protection at a disadvantage, as they are more likely to be dependent whether financially, emotionally or otherwise on a member of their family.

\section{Procedural deLAys}

Ireland is not alone among refugee-receiving countries in failing to provide an expeditious family reunification application process. According to Professor Hathaway, "there are often prolonged delays in authorising family reunification in developed states". ${ }^{79}$ Neither the Convention nor the Committee on the Rights of the Child have defined "expeditious" in relation to family reunifications, however, the protracted nature of the process in many cases in Ireland could hardly be said to fulfil the state's obligations in this regard. Many applications take at least two years to be processed to completion and some take even longer. ${ }^{80}$

Applications for family reunification are dealt with in chronological order and applications involving children are not prioritised. The European Council on Refugees and Exiles (ECRE) has recommended that applications for family reunification from or regarding separated children should be prioritised given the negative impact of prolonged separation from their parents. It further recommends that all applications for family reunification should be processed within a six-month timeframe. ${ }^{81}$

In a case before the Irish High Court involving an application for family reunification made by a refugee for his wife and minor children where a four-year delay occurred in determining the application, the court held that:

The requirements of constitutional justice dictate that an applicant seeking administrative relief, whether in the immigration context or otherwise, is entitled

77 N Mooten, Making Separated Children Visible: The need for a child-centred approach (Dublin: Irish Refugee Council 2006).

78 The Trinity Immigration Initiative Report describes the experiences of one young Somali woman who arrived in the state aged 17 as a separated child in 2005 and applied for family reunification for her widowed father and her five siblings on receipt of a declaration as a refugee in 2006. In 2010, she was finally informed that only her father had been granted family reunification. Moreo and Lentin, From Catastrophe to Marginalisation, n. 11 above, p.47.

79 J Hathaway, The Rights of Refugee under International Law (Cambridge: CUP 2005), p. 537.

80 See n. 77 above.

81 ECRE, Position on Refugee Family Reunification (Brussels: ECRE July 2000). 
to a decision within a reasonable time ... The applicant in the present case applied for family reunification in June 2003 and did not receive a decision until August 2007, there was, therefore, a delay of over 4 years. This is a most unsatisfactory state of affairs. ${ }^{82}$

While the court did not set out what could be considered a reasonable time in which to process family reunification applications, it is clear that a delay of four years is excessive. In this case, children were the subjects of the application and it would appear reasonable to suggest that due regard was not given by the minister to the best interests of these children. As the CRC has not been incorporated into Irish law, the state's obligations under the Convention in relation to ensuring that applications for family reunification are dealt with in an expeditious manner were not addressed by the court.

\section{FAILURE TO CONSIDER THE VIEWS OF THE CHILD}

While separated children who have been granted a declaration as a refugee or are beneficiaries of subsidiary protection may apply to be joined by family members, their applications are processed in a similar manner to those of adult applicants. In addition, child-appropriate information regarding the right to family reunification and the procedure involved are not made available to children. The Committee on the Rights of the Child has emphasised through General Comment No. 12 the requirement on states to ensure that the views of children are taken into account in matters concerning them.

Neither s. 18 of the Refugee Act 1996 (as amended) nor s. 16 of the European Communities (Eligibility for Protection) Regulations 2006 address the specific needs of children in the family reunification process, in particular separated children. Little detail is provided in the legislation on the procedure for determining applications for family reunification. For example, while it is clear that the Refugee Applications Commissioner is tasked with carrying out an investigation and submitting a report to the minister, it is unclear whether the minister can make further inquiries or indeed carry out an additional investigation. There is no provision for an oral interview nor for the making of representations or submission of new information. In order to comply with the state's obligations under Article 12 of the Convention, a mechanism for ensuring that the views of children are heard and considered in the family reunification process must be implemented and this should include the provision of age-appropriate information and support.

\section{IRELAND'S REPORT TO THE COMMITTEE ON THE RIGHTS OF THE CHILD}

Ireland presented its last periodic report to the Committee on the Rights of the Child in 2006. In the case of Ireland, the Committee was of the view that the Refugee Act 1966 (as amended) provides for an adequate legal framework for family reunification for refugees. However, it reminded Ireland that family reunification in accordance with Article 10 of the Convention also applies to other situations and that family members in such situations do not have access to procedural information, and that the principle of the best interests of the child is not taken into account in the decision-making process.

It also recommended that Ireland should:

(a) consider reviewing the definition of family in the Refugee Act 1996 to better correspond to the developing understanding of the family;

(b) consider establishing a legal framework for family reunification outside situations under the Refugee Act; and 
(c) ensure that the principle of the best interests of the child is always a primary consideration when making decisions involving children under any legal or administrative procedures. ${ }^{83}$

Ireland has largely ignored these recommendations. Despite the recommendations of the Committee on the Rights of the Child, the Immigration, Residence and Protection Bill 2010, which will replace existing legislation in relation to asylum and immigration, does not extend the definition of the family and fails to provide for family reunification for other migrants. Ireland only recognises the family based on marriage for the purposes of family reunification. An unmarried refugee or beneficiary of subsidiary protection is not permitted to apply to be joined by his or her partner whether heterosexual or same sex. This does not change where children are involved and a situation could arise under the current family reunification regime where a refugee or beneficiary of protection who is not legally married but in a long-term relationship may be joined by his or her children but not by the other parent of those children.

\section{Conclusion}

Although the Convention does not confer a "right" to family reunification on children or their families, it can be argued that states' obligations regarding family reunification under the Convention are stronger than those set out in other human rights conventions. In addition, the Committee on the Rights of the Child has demonstrated its commitment to ensuring that states comply fully with and implement in a generous way the provisions of the CRC as they relate to family reunification. The Committee recognises the vulnerable situation of unaccompanied and separated children and emphasises the duty on states to ensure that the views of children be heard in all matters concerning them.

The Committee on the Rights of the Child has addressed specific issues in relation to states' implementation of the CRC: the length of the process; the failure of states to provide information to children on their rights to family reunification; the definition of family for the purposes of family reunification; and more restrictive criteria for refugees, including DNA and language testing, in reunifying with their family. It has gone further to urge states to consider permitting family reunification in situations where children or their families have been granted temporary protection or humanitarian status.

It can be argued that, while beneficiaries of international protection in Ireland have a statutory right to family reunification, the state is failing in its obligations under the CRC. The narrow definition of family set out in legislation and the application process, which is beset with bureaucracy and lengthy delays, raise questions regarding the state's commitment to the full implementation of the CRC. Ireland's legislation and policy regarding family reunification cannot be viewed in isolation from its attempts to control migration, including the numbers of applications for a declaration as a refugee. However, the Committee on the Rights of the Child has been unambiguous in emphasising that the rights of children to reunification with their families should not be compromised in the interests of immigration control. The state must at a minimum ensure that the recommendations of the Committee in its concluding comments on Ireland's last periodic report are complied with.

83 Committee on the Rights of the Child, 43rd session, considering reports submitted by states parties under Article 44 of the CRC, Concluding Observations on Ireland, paras 30 and 31. 